\title{
She is from the East
}

\section{Florence Boulard}

\author{
James Cook University
}

\section{ook to the East, there is nothing.
Look again, you are misjudging.}

Look to the East and you may meet whom I see.

Mermaid of the Pacific, tears transformed into black pearls, Travelling by sea the beatific faces of Gauguin,

This exotic Vahine wearing a tiaré can be found in acrylics, But most importantly she has found her place on my lips.

Look to the East and you may meet whom I see.

Eloquent Queen Amelia fighting with grace for peace,

Kele ma'uli, she stands tall, resembling a tree.

Female politician of 1881 , she flew above the sea,

But most importantly, she prayed for the same people as me.

Look to the East and you may meet whom I see.

Linguistic heaven in the soul of Melanesia,

Flirtatious, dangerous, courageous

She is your mother, she is your sister, she is your daughter.

Be reassured Yasur keeps a close eye on her.

Look to the East and you may meet whom I see.

This is worth more than green gold to me,

Floating in her missionary dress she gives life to thee.

Remember to be.

Remember to look to the sea. 